\title{
Planning for Demographic Diversity: The Case of Immigrants and Public Transit
}

\author{
Evelyn Blumenberg, UCLA Institute for Transportation Studies \\ Alexandra Elizabeth Evans, Louisiana Recovery Authority
}

\begin{abstract}
This research examines the significant effects of immigration on transit use. Drawing on data from the U.S. Census, we examine how the enormous influx of immigrants to California has altered the demographics of transit commuting in the state and contributed importantly to a growth in transit ridership. California immigrants commute by public transit at twice the rate of native-born commuters, comprise nearly 50 percent of all transit commuters in the state, and are responsible for much of the growth in transit commuting in the state. But over time, immigrants' reliance on transit declines. Transit managers would be well advised to plan for these inevitable demographic changes by enhancing transit services in neighborhoods that serve as ports to entry for new immigrants, those most likely to rely on public transportation.
\end{abstract}

\section{Introduction}

Immigration to the U.S. continues to change both the size and composition of the nation's population. Although dispersing over time, immigrants remain highly concentrated in particular states and metropolitan areas. In 2008, 22 percent of all legal immigrants to the U.S.-almost one quarter million $(238,444)$ personssettled in California, a figure substantially larger than for any other state (U.S. Department of Homeland Security 2008). Census data show that the foreign-born 
population now comprises more than one quarter of the California population (26\%), with Latinos the dominant foreign-born group in the state. Most analysts predict that the elevated immigration rates of the 1990s will slow (Passel and Cohn 2008; Myers et al. 2005), but continued immigration coupled with the already substantial size of the immigrant population will affect the American demographic landscape for years to come.

The recent political focus on immigration reform has sparked interest among both policymakers and the public in the costs and benefits associated with a growing immigrant population. Numerous studies have examined the economic, social, and cultural trajectories of immigrants in the U.S. However, academic scholarship on the relationship between immigration and daily travel is sparse, particularly regarding public transit use upon which recent immigrants tend to heavily rely.

In this study, we examine the impact of immigrants on public transit commuting in California. We draw on data from the 1980, 1990, and 2000 Integrated Public Use Microdata Series of the U.S. Census (Ruggles et al. 2004) to examine trends in transit commuting in California by immigrant workers. We then use censustract level data from the 2000 Census Summary File 3 to examine the relationship between immigrants and transit commuting, controlling for other factors that influence transit use. Combined, these analyses demonstrate the important role of immigrants in both maintaining transit ridership as well as in predicting areas within metropolitan areas that are likely to have the highest rates of transit commuting.

However, with time in the U.S., transit use among immigrants declines. Recent immigrants today are less likely to use transit than recent immigrants in previous decades. Holding all else constant, these patterns coupled with the predicted slowdown in immigration likely will have a negative effect on transit ridership. We conclude from this analysis that transit managers would be well advised to plan for these inevitable demographic changes. One way in which transit agencies can address the potential loss of immigrant riders is to better meet the needs of newlyarrived immigrants by enhancing transit services in neighborhoods that serve as ports of entry for recent immigrants.

\section{Immigrants and Transit Ridership}

As the schematic in Figure 1 suggests, immigration's effect on transit ridership operates through a number of demand- and supply-side factors. At a macro level, 
immigration contributes to population and employment growth and, therefore, to transit ridership. At a more micro level, studies show that immigrants are more likely to travel by public transit than native-born adults. Yet despite immigrants' disproportionate use of public transit, the evidence suggests that immigration's contribution to transit ridership diminishes over time, as immigration to the U.S. slows and immigrants gradually assimilate to the auto-oriented travel patterns of the native born.

Immigration positively affects population size, which, in turn, correlates with transit demand. Studies show that public transit ridership is positively related to population size since larger cities or metropolitan areas have a greater number of potential transit riders (Taylor et al. 2009; Kain and Liu 1995, 1998, 1998). In recent years, immigration has had a substantial effect on the size of the California population. Immigration accounted for less than 10 percent of the state's population growth in the three decades prior to the 1970s; however, this figure rose to almost 50 percent, becoming the dominant factor in population growth in more recent years (McCarthy and Vernez 1997). With the slowing of immigration since 2002, natural increase (that is, the increase in population due to births minus deaths) has become the major source of population growth. In 2005, 64 percent of California's population growth was due to natural increase, with the remaining 36 percent attributed to net migration (California Department of Finance 2006). Immigration also expedites the natural increase in the population in cases where immigrants have higher birthrates than the native-born population. In California, the birthrates among Hispanics and Asian immigrants are significantly higher than those of the native-born (Hill and Johnson 2002).

Aggregate transit ridership levels are linked to the health of the economy, which many economists argue is enhanced by immigrant labor (Council of Economic Advisors 2007). However, the economy's effect on transit ridership can be contradictory. Economic prosperity increases employment and employment rates, which, in turn, generate additional commute trips (Taylor and McCullough 1998; Taylor et al. 2009; Kain and Liu 1995, 1998, 1998), some of which are likely to occur on public transit. At the same time, a robust economy generates positive income effects, enabling some transit-dependent families to purchase and drive automobiles, thereby reducing their reliance on public transit (Lave 1992).

Residential location is similarly important to transit ridership, as locating in areas of greater population density implies better access to transit supply and higher levels of transit use (Cervero 2002; Kain and Liu 1999; Ming 2006; Taylor et al. 2009; 


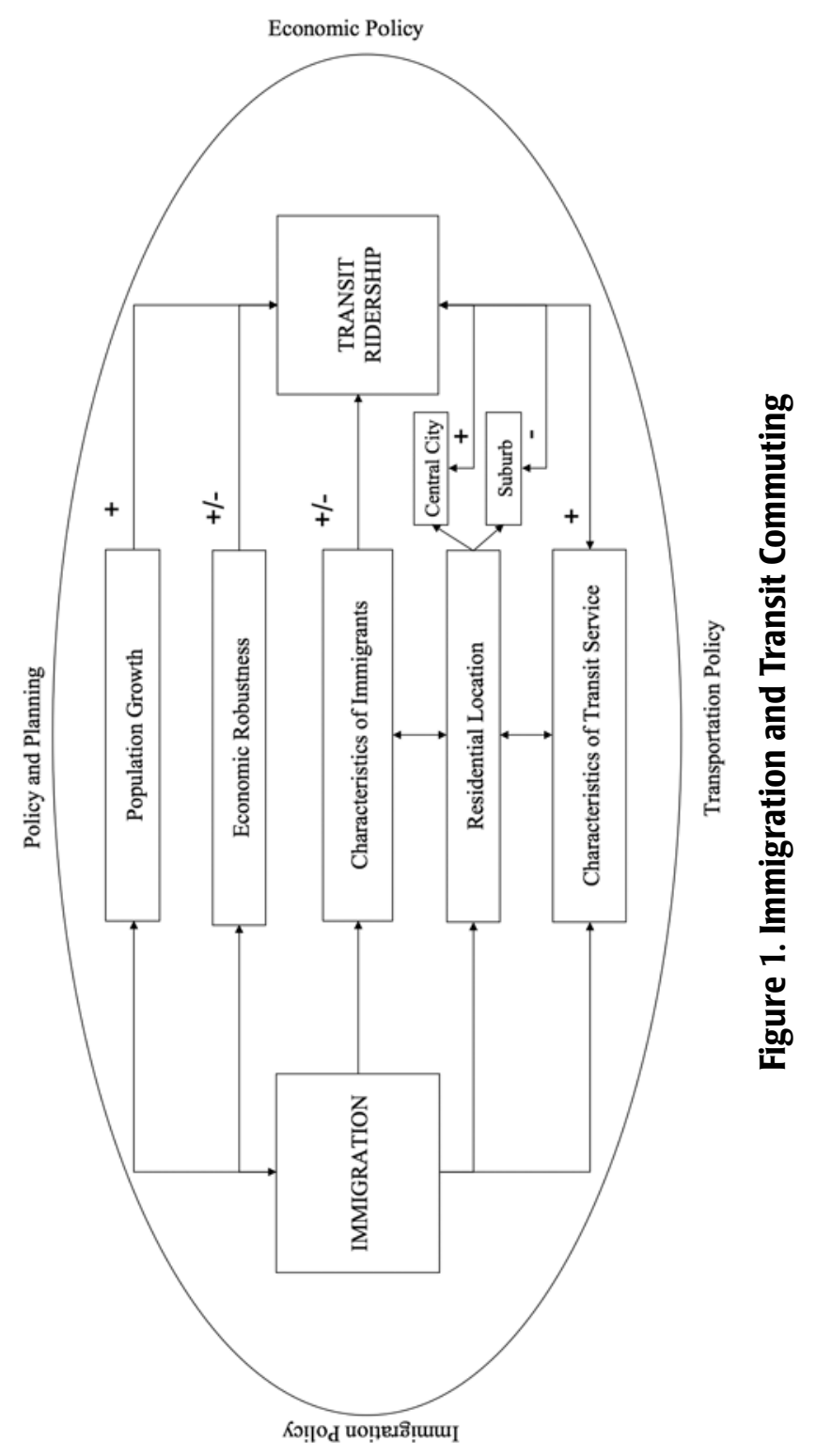


Transportation Research Board 1997). Dense development reduces distances between trip origins and destinations, increasing transit's appeal to potential users. Immigrants have established dense urban neighborhoods; often termed "ethnic enclaves," these neighborhoods contain clusters of immigrant residences, businesses, services, and institutions that cater to the needs of particular ethnic groups (Logan et al. 2002). Such clusters most often are located in central-city neighborhoods where housing is relatively affordable and transit networks extensive. As immigrants assimilate, many relocate to the suburbs-sometimes even to suburban ethnic neighborhoods-where transit service tends to be more limited, travel distances are greater, and cars thus become a superior mode of travel (Blumenberg 2009).

Demographic characteristics further relate to transit use, which is highest among those with limited or no access to automobiles because of age, income, or disability (Polzin et al. 2000). Sex, race/ethnicity, and educational attainment affect transit use, as women, racial/ethnic minorities, and those with less formal education are more likely to use transit than other population groups (Rosenbloom 1998). Direct causal relationships are difficult to establish, since many demographic characteristics are highly collinear with both income and auto access. Like other minority groups, immigrants cross many of the principal markets for public transit. They are more likely to be non-white and to have lower incomes compared to native-born adults and, hence, are twice as reliant on public transportation (Rosenbloom 1998).

For immigrants and native-born alike, transit demand fluctuates in response to the time and monetary cost of transit's principal substitute-the automobile. Travelers tend to prefer the automobile to public transit in terms of comfort, reliability, travel time, and flexibility and, therefore, are willing to pay more to drive than to take public transit. In general, transit use is negatively related to automobile access (McFadden 1974; Taylor et al. 2009); census data show that zero-vehicle households are almost six times more likely than households with cars to commute by transit. Income is one of the primary determinants of vehicle ownership (Schimek 1996). Immigrants have higher poverty rates and lower incomes than native-born adults, making the decision to purchase vehicles more financially onerous for immigrant families as a group than native-born families (Chapman and Bernstein 2003). More settled immigrant households-those who have been in the U.S. 10 years or longer-are twice as likely as recent immigrant households 
to own vehicles; however, they are still half as likely to own vehicles as native-born households (McGuckin and Srinivasan 2003).

Nevertheless, the transit-commuting patterns of immigrants differ from nativeborn whites, even controlling for income and other determinants of transit use (Blumenberg and Shiki 2007; Blumenberg and Smart forthcoming). Automobile ownership levels, driving propensities in immigrant countries of origin, and other factors including cultural differences may account for variations in transit use across immigrant groups. With respect to immigrants, a lack of driving experience also may be a significant barrier to auto ownership, particularly among immigrant families who had little or no access to automobiles in their countries of origin. Although auto ownership is increasing rapidly in many developing countries, large variation in automobile ownership among countries remains. Data from a sample of world cities show that in 1995 there were 26 passenger cars per 1,000 persons in China; 202 passenger cars per 1,000 persons in Latin America; and 587 passenger cars per 1,000 persons in the U.S. (Kenworthy and Laube 2002). Cultural variation in women's roles also may influence travel behavior. Compared to women in the U.S., women living in many other countries are much less likely to possess driver's licenses or to know how to operate vehicles (Pisarski 1999).

Yet, the influence of immigration on transit ridership likely has declined over time. For one, immigration is still increasing but at a decreasing rate (Myers 2008). Moreover, immigrants tend to assimilate toward the travel patterns of nativeborn adults (Myers 1996; Blumenberg and Shiki 2007; Rosenbloom 1998; Casas et al. 2004; Heisz and Schellenberg 2004; McGuckin and Srinivasan 2003). Increased earnings and household incomes allow immigrants to purchase automobiles and reduce their dependence on public transit.

A number of previous studies have used microdata-data on individuals-to examine the determinants of transit use among immigrants (Blumenberg and Shiki 2007; Blumenberg and Smart forthcoming; Heisz and Schellenberg 2004; Tal and Handy 2010). However, far less research has relied on aggregate data to examine the impact of immigration on transit ridership levels across geographic areas and, over time, the focus of this study.

\section{Research and Design}

To examine the effect of immigrants on public transit commuting in California, we begin with an analysis of commute mode trends for native- versus foreign-born 
adults from 1980 to 2000 using data from the Integrated Public Use Microdata Series (IPUMS) of the U.S. Census (Ruggles et al. 2004). The Census microdata are the best available source of information on the travel of immigrants in California. They include large sample sizes that allow for analysis of relatively small population groups and detailed demographic information for each adult, including race and ethnicity, immigrant status, and year of arrival.

One drawback to using these data, however, is the limited number of transportation-related variables. The primary question related to travel mode focuses on journey-to-work travel and, more specifically, how respondents "usually" traveled to work in the week prior to the survey. As such, transit use is underreported if respondents used transit only sporadically for work and for trips other than the commute; however, transit mode share tends to be highest for the commute (Polzin and Chu 2005). Ideally, we would have data on transit ridership over time by nativity; however, these data are unavailable. Therefore, we use transit commuting as a proxy-albeit an imperfect one-for transit ridership in general.

A second drawback of the PUMS data set is that, for confidentiality reasons, it includes very limited geographic information on the residential location of respondents and, therefore, limits our ability to examine the relationship between neighborhood characteristics and transit use. To examine this relationship, in the second part of the analysis, we draw on census-tract level data from the Neighborhood Change Database (Urban Institute 2004) to model the relationship between the percentage of immigrants and transit use by census tract for 1980, 1990, and 2000, controlling for other neighborhood characteristics.

A third drawback to Census data is that they lack information on characteristics of transit systems such as transit service levels, coverage, and fares. Such data at the statewide level do not exist in California. Therefore, the statistical models presented later in the paper are underspecified. To minimize this limitation particularly related to service levels and coverage, we control for the eight largest cities in California, where transit networks are the most extensive. Within urban areas, we use population density as a proxy for transit service levels. However, relationships-between large, dense urban areas and transit use-are endogenous. Transit agencies tend to provide higher levels of service in dense urban areas than in dispersed outlying suburbs, since ridership in these areas tends to be relatively high (Taylor et al. 2009). At the same time, transit-dependent population groups are more likely to live in dense urban areas where they can rely with greater ease on public transit (Glaeser et al. 2008). While transit service data are 
available by transit agency, they are difficult to use in a census-tract level analysis; transit service areas overlap and, therefore, residents-particularly in areas where transit usage is highest-likely use multiple providers. The price of transit-or the fare-influences transit usage. However, its effect on transit use tends to be less significant than that of transit service levels (Cervero 1990; Kain and Liu 1996; Kain and Liu 1999).

Finally, the most recent census-tract-level data are for 2000, almost 10 years old. Unfortunately, more recent census-tract level data are unavailable. We hope that this analysis can provide an important point of reference from which we can revisit the travel behavior of native- and foreign-born persons using the 2010 Decennial Census data when they become available.

\section{Immigrants and Public Transit Commuting in California (2000)}

Like other commuters, most immigrants travel to work by automobile. In 2000, almost 90 percent of California's foreign-born population commuted by car and just 8 percent by public transit. Still, as Figure 2 shows, immigrants in California commute by public transit at rates twice that of native-born adults. Further, statewide data mask substantial differences in public transit use among particular immigrant groups and across urban areas. Some immigrant groups, such as those from Guatemala (19\%), El Salvador (16\%), and China (13\%), have rates of transit use substantially higher than the average for all foreign-born commuters (8\%). Public transit use varies widely across metropolitan areas, with the highest levels of patronage concentrated in the very largest U.S. urban areas such as New York and San Francisco, areas that have residential and employment densities conducive to public transit use. As Figure 3 shows, public transit usage rates among immigrants in San Francisco (23\%) are higher than for any other metropolitan area in the state. However, the ratio between the public transit usage rates between foreignand native-born commuters is largest in Southern California-in Orange and Los Angeles counties where 37 percent of the California population lives. The data suggest that immigrants are much more likely to use transit in metropolitan areas where transit is available but overall transit usage rates are relatively low. Conversely, their use of public transit is more similar to that of native-born adults in metropolitan areas where either transit rates are high (San Francisco and Oakland) and public transit works well for many residents and in areas where public transit service is limited (i.e., San Bernardino, Fresno). 


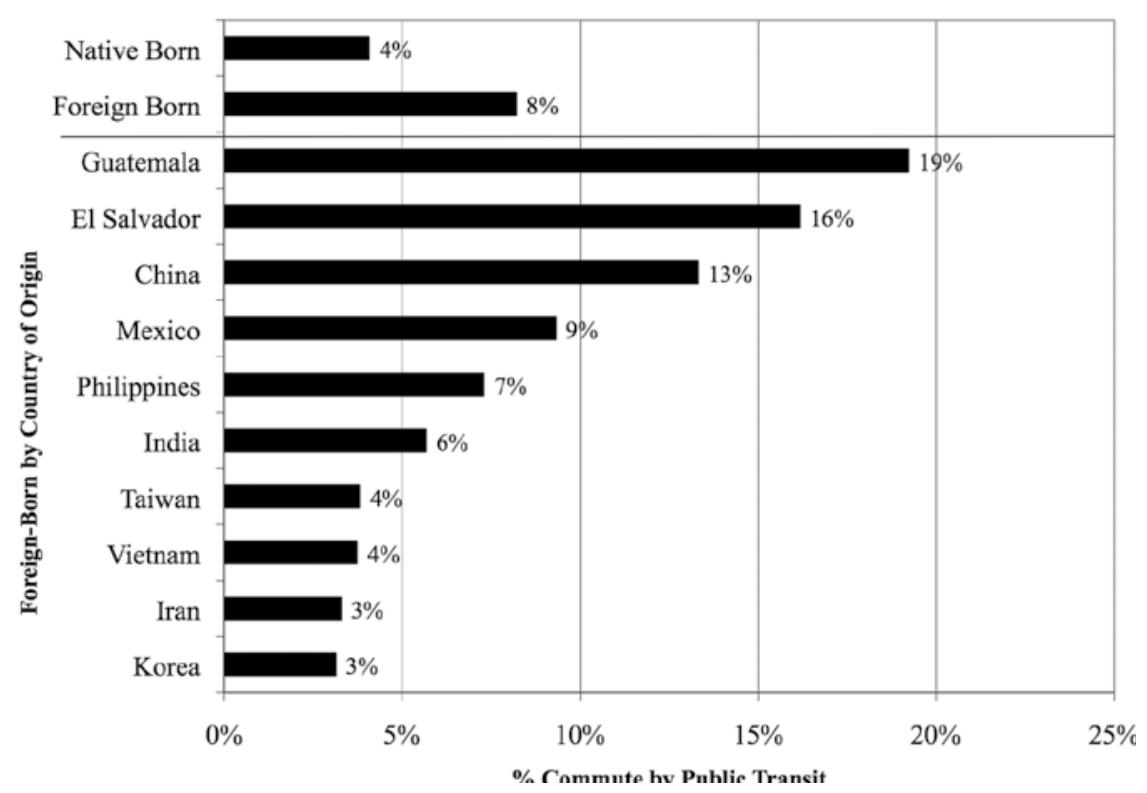

Figure 2. Public Transit Commuting by Nativity and Country of Origin (2000)

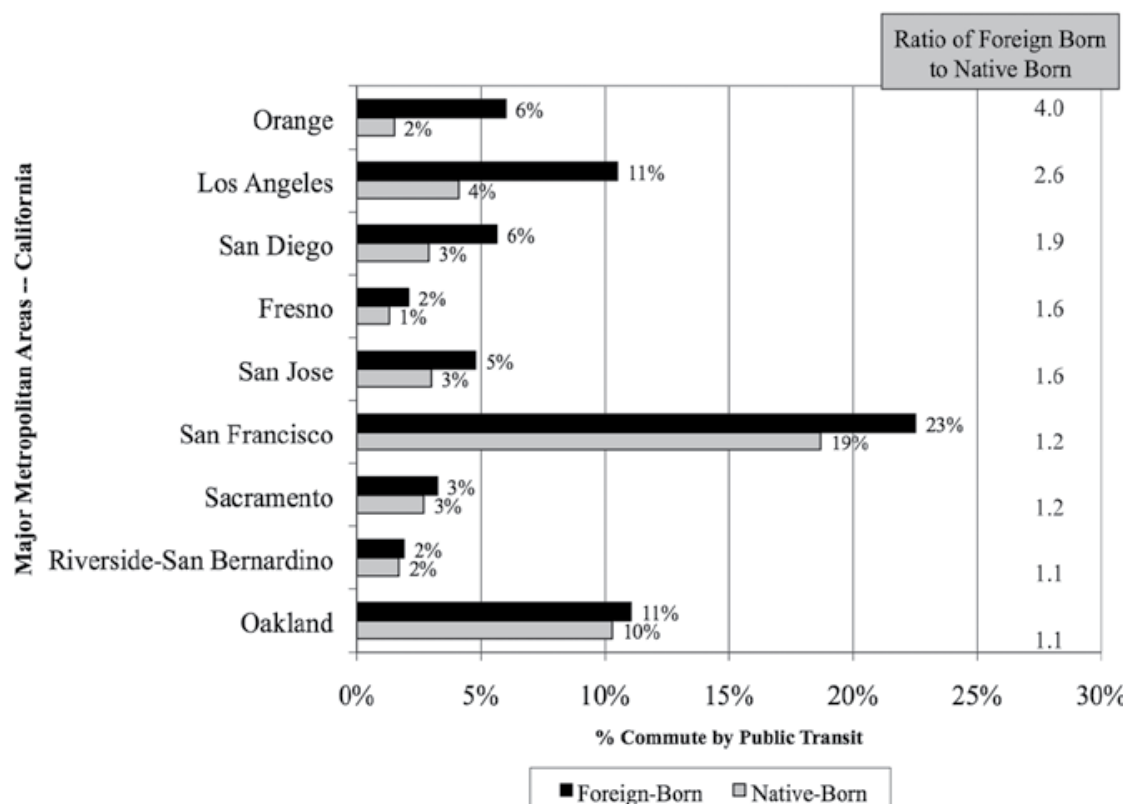

Figure 3. Public Transit Commuting by Nativity and Metropolitan Area (2000) 
With growing acculturation, immigrants tend to transportation assimilate; in other words, with time in the U.S., they gradually assume the travel patterns of native-born workers (Blumenberg and Shiki 2007; Myers 1996; Tal and Handy, 2010). However, some immigrant groups, particularly immigrants from Latin America, have such high rates of transit use upon arrival that they remain more likely than native-born white commuters to commute by public transit even after many years of residence in the U.S. Figure 4 shows the transit usage rates of immigrants in California by race/ethnicity and year of arrival. Almost one-quarter of recent Hispanic immigrants-those who have lived in the U.S. less than six yearscommute by public transit. After more than 20 years in the U.S., both Hispanic and Asian immigrants still rely on public transit in rates higher than native-born commuters.

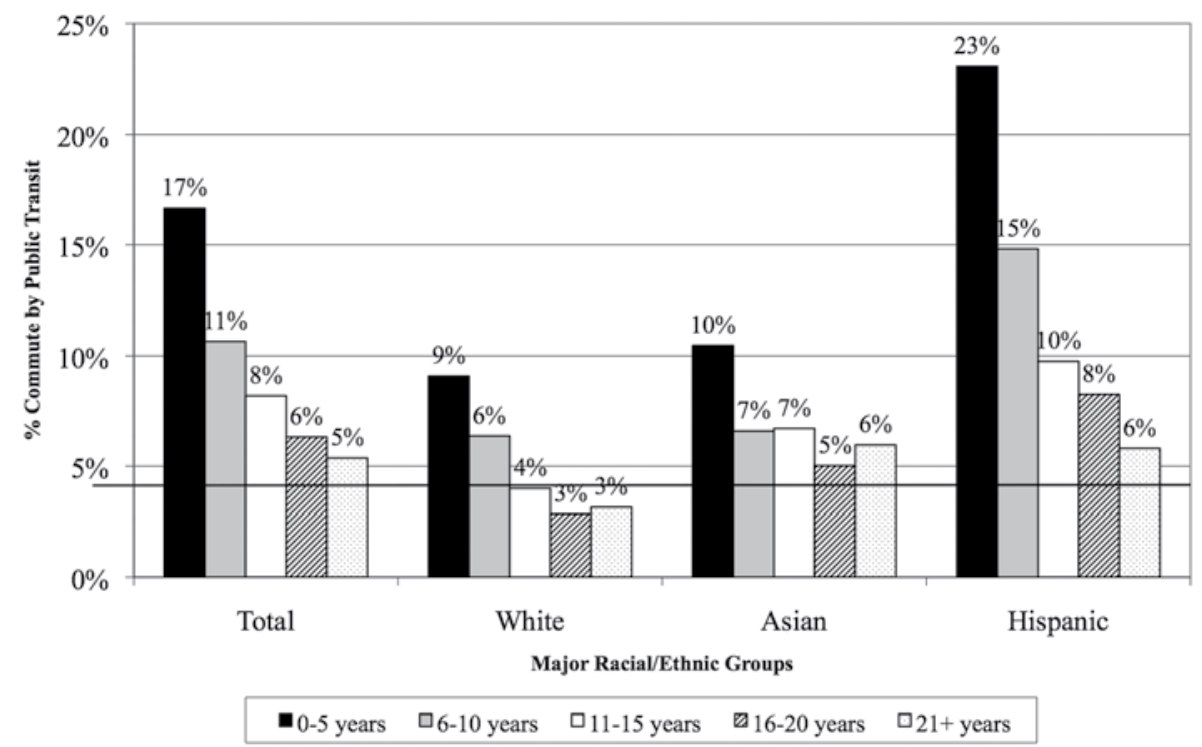

*Line indicates $4 \%$ transit commute rate among native-born workers.

Figure 4. Public Transit Commuting by Race/Ethnicity and Year of Arrival (2000)

\section{Immigrants and Transit Commuting, 1980-2000}

Cumulatively, these trends have affected the size and composition of public transit commuters in the state. Drawing on data from the 1980, 1990, and 2000 U.S. Censuses, we examine changes in transit commuting by nativity; these trends are 
depicted in Figure 5. To distinguish the contribution of recent immigrants from more-established immigrants, we categorize immigrants as follows: new or recent immigrants who, at the time of the U.S. Census, had lived in the U.S. for less than 10 years, and more settled immigrants who had lived in the U.S. for 10 or more years.

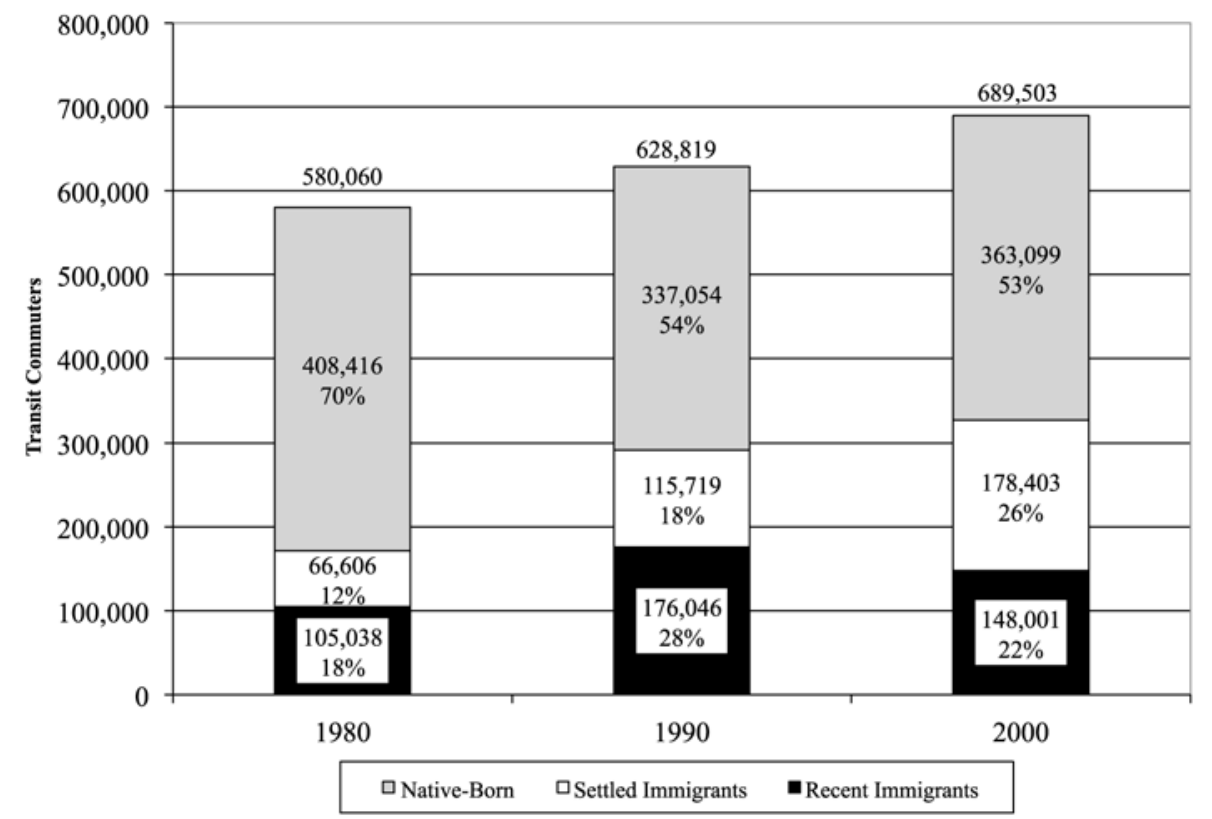

Figure 5. Transit Commuting in California by Nativity, 1980-2000

Figure 5 shows that California experienced a 19 percent increase in the total number of transit commuters between 1980 and 2000, an increase almost entirely attributable to immigrants. ${ }^{1}$ Transit commuting among native-born adults dipped substantially during the 1980 s, declining by more than 17 percent. It then rose by less than 8 percent during the 1990s, approximately 11 percent below 1980 levels. In contrast, the number of immigrant transit commuters grew throughout this period. The largest growth in immigrant transit commuting - a 70 percent increase-occurred during the 1980s, a decade in which immigration to both the U.S. and California rose rapidly. Immigration peaked in 1991 when almost 2 million legal immigrants and refugees entered the U.S. (Office of Immigration Statistics 2008). In the subsequent decade, the growth in immigrant transit commuters slowed, paralleling the slowdown in immigration flows to the U.S. During 
this decade, the number of immigrant transit commuters increased modestly by 12 percent.

These trends resulted in a substantial shift in the composition of transit commuters in the state. In 1980, 30 percent of all transit commuters were foreign born; by 2000 , immigrants comprised almost half ( $47 \%$ ) of all transit commuters in the state. Among immigrant transit commuters, the majority are Hispanic (65\%) and the remainder are Asian (24\%), white (7\%), and black (1\%). In some California metropolitan areas, the percentage of immigrant transit commuters is substantially higher than the state average. For example, immigrants in Los Angeles comprised 36 percent of the population but nearly two-thirds of all transit commuters.

Figure 5 also highlights the shifting tenure composition of immigrant transit commuters showing more established or settled immigrants as a growing share of transit commuters. The percentage and the number of recent immigrants, defined here as immigrants who arrived during the decade prior to each census, increased substantially from 1980 to 1990 and then declined between 1990 and 2000. These figures reflect a number of different trends. By 2000, we see the remaining cohort effects from high immigration in previous decades. However, not all recent immigrant transit users remain transit users across decades; as mentioned previously, immigrants are less likely to use public transit with time in the U.S.

The number and characteristics of recent immigrants also have changed. In particular, recent immigrants in 2000 were fewer and slightly less reliant on public transit than were earlier cohorts of recent immigrants. In 1980, 14.5 percent of recent immigrants commuted by transit compared to just over 12 percent in 2000 . This last finding may be due to changes in the composition of immigrant migrants; for example, recent immigrants in $\mathbf{2 0 0 0}$ may have higher incomes upon arrival and, therefore, be better able to afford automobile ownership or they may migrate from countries where auto use is prevalent. These patterns also could be explained by the growth in auto use internationally and changes in the propensity to drive.

Without immigrants and absent other changes, the number of transit commuters in California would be significantly lower than current levels by almost 50 percent. Nonetheless, the percentage of commuters who travel by public transit has remained relatively constant over time despite substantial public investments in transit services over this period. For example, total public expenditures on transit in California increased from \$248.6 million in 1991 to $\$ 1.9$ billion in 2000, a 644 percent increase in transit funding (Federal Transit Administration 2009). ${ }^{2}$ Yet, 
the percentage of transit commuters in the state declined from 6 percent in 1980 to 5 percent in 1990 and remained just above 5 percent in 2000. Over this time period, public transit commute rates among immigrants declined from 11 percent to 8 percent.

\section{Transit Use and the Independent Effect of Immigrants}

These descriptive data are instructive; however, they do not allow us to examine the factors that influence public transit usage. To do so, we use ordinary least squares (OLS) models to analyze the independent effect of immigrants on transit use over three time periods-1980, 1990, and 2000. In these models, we focus on the relative influence of immigrants, controlling for a variety of other factors. The models take the following specification:

$$
\mathrm{T}_{i}=\mathrm{a}_{i}+\mathrm{x}_{i} \beta+\varepsilon_{i} \text { for } i=1 \ldots \text { n tracts }
$$

where $\mathrm{x}_{i}$ is the vector of observed values for the listed independent variables for tract $i, \beta$ is a vector of coefficients, and $\varepsilon_{i}$ is the stochastic term that is assumed to have an expected value of 0 and a normal distribution. We hypothesize that the correlation between percent foreign-born and percent transit commuting, while exhibiting a strong positive relationship in all three census years, would have declined over time due to assimilation and broader changes in demography and travel behavior. Our results support this hypothesis.

Table 1 lists the variables, their hypothesized relationship to transit commuting, and their means. To isolate the effect of immigrants on public transit commuting, we controlled for the characteristics of census-tract residents including their foreign-born status and race/ethnicity. Poverty status and the percentage of zerovehicle households - both strong predictors of transit use-are highly correlated. To overcome this problem, we created an index combining the effects of poverty rate and zero-vehicle households on transit use. Finally, to capture the effects of residential location as well as the relative supply of public transit, which is likely to be higher in large cities and dense urban areas, we included three variablespopulation density, the percentage of the housing stock built prior to 1939 (serving as a proxy for central-city neighborhoods), and the eight most populous cities in the state. 


\section{Table 1. Spatial Variation in Transit Use Model Variables}

\begin{tabular}{|l|c|c|c|c|}
\hline & Hypothesized & \multicolumn{3}{|c|}{ Means } \\
\cline { 3 - 5 } Variables & Relationship & $\mathbf{1 9 8 0}$ & $\mathbf{1 9 9 0}$ & $\mathbf{2 0 0 0}$ \\
\hline \% Commute by Transit & Dependent Variable & $5.7 \%$ & $5.2 \%$ & $5.6 \%$ \\
\hline \% Foreign Born & + & $15.0 \%$ & $21.1 \%$ & $25.5 \%$ \\
\hline$\%$ White & - & $67.3 \%$ & $58.6 \%$ & $49.9 \%$ \\
\hline \% Black & + & $7.3 \%$ & $7.0 \%$ & $6.6 \%$ \\
\hline$\%$ Hispanic & $?$ & $19.2 \%$ & $24.6 \%$ & $31.8 \%$ \\
\hline$\%$ Asian & $?$ & $5.4 \%$ & $9.3 \%$ & $11.1 \%$ \\
\hline$\%$ Other & $?$ & $0.7 \%$ & $14.4 \%$ & $0.8 \%$ \\
\hline Poverty*Car & + & $1.8 \%$ & $1.8 \%$ & $2.2 \%$ \\
\hline Poverty Rate & + & $11.5 \%$ & $12.5 \%$ & $14.3 \%$ \\
\hline$\%$ in 0-Vehicle Households & + & $9.4 \%$ & $8.9 \%$ & $9.8 \%$ \\
\hline Population Density & + & 6,056 & 7,382 & 8,041 \\
\hline$\%$ Pre-1939 Structures & + & $13.5 \%$ & $10.7 \%$ & $9.8 \%$ \\
\hline Los Angeles & + & & $11.0 \%$ & \\
\hline San Diego & + & & $3.5 \%$ & \\
\hline San Jose & + & & $2.3 \%$ & \\
\hline San Francisco & + & & $1.2 \%$ & \\
\hline Long Beach & + & & $1.4 \%$ & \\
\hline Fresno & + & & & \\
\hline Sacramento & + & & & \\
\hline Oakland & + & & & \\
\hline
\end{tabular}

Table 2 presents the results for each of the census years. As expected using aggregate data, the models explain a large percentage of the variation with adjusted $\mathrm{R}^{2}$ values of 0.74 or higher. Apart from living in San Francisco, the strongest predictor of transit use in 1980 and 1990 is the percentage of foreign-born (with standardized estimates of 0.313 and 0.368 , respectively). By 2000, however, the models suggest a waning role for immigrants in explaining transit use. In this most recent census year, the percentage of the census tract population that is foreign-born still is significant, but less important than the poverty rate/zero-vehicle index. 


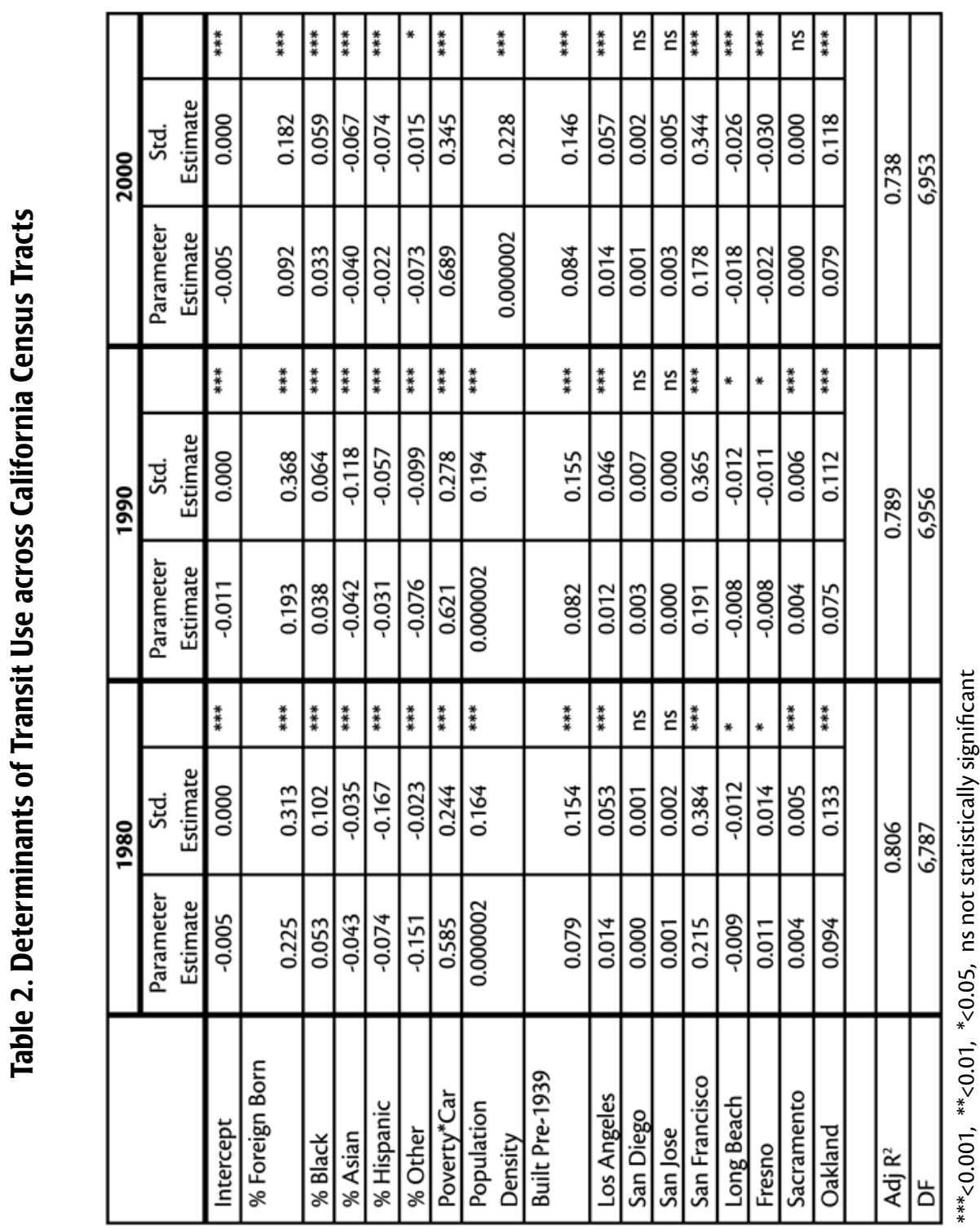


Certainly to be taken with some caution, given the level of aggregation, the results are supportive of the findings of the descriptive analysis. Immigrants are an important predictor of transit use across geographic areas. However, their effect on transit commuting in California is waning, as demonstrated by its declining importance in predicting transit use in 2000 . This finding may be the result of immigrants' assimilation to auto use over time. It also might be explained by the slowdown in the growth of California's immigrant population and, therefore, a decline in the number of recent immigrants, those most reliant on public transit. Data from the U.S. Census show that the foreign-born population in California increased by 80 percent from 1980 to 1990 but by only 37 percent from 1990 to 2000 (Gibson and Lennon 1999; U.S. Census Bureau 1990 and 2000). Still "percent immigrant" is strongly related to transit use.

\section{Immigrants and Transit-Analysis and Policy Prescriptions}

Forecasting the future is difficult, particularly since immigration largely is determined by federal immigration policy, currently the focus of national political attention. However, future trends in immigration, immigrant transit use, and immigrant residential location patterns suggest that transit agencies in California-and other traditional immigrant ports of entry-ought to be concerned about their ridership and, therefore, adopt ridership retention policies to retain immigrant transit users.

Unless transit agencies intervene, with time in the U.S., the foreign-born population-a historically dependable transit market-will continue to assimilate away from public transit. Compounding these trends are population forecasts that indicate that future immigration will occur at a slower pace than in previous decades (Myers et al. 2005; Passel and Cohn 2008). While recent immigrants substantially contributed to the increase in transit ridership in California from 1980 to 1990, their influence dwindled in 2000 and likely will continue to decline in tandem with immigrant growth rates. Further, the evolving residential location patterns of immigrants also pose a threat to transit agencies. Over time, fewer immigrants to the U.S. settle in traditional port-of-entry states such as California. In 1998, 26 percent of those who obtained legal permanent residency in the U.S. resided in California, a figure that declined to 22 percent in 2007 (Office of Immigration Statistics 2008). At the same time, immigrants increasingly live in the suburbs-both in California and nationally-where transit networks are sparse and residents are more likely to rely on automobiles (Singer 2004). 
The absolute size and continued growth of immigrant communities throughout the U.S. underscores the relevance of immigrants to transit agencies. Transit agencies must either find ways to retain immigrant riders or fill the ridership gap with other travel markets. In the last 10 years, researchers have recognized the importance not only of attracting new choice riders but also of retaining existing riders as perhaps a more cost effective strategy for maintaining transit ridership levels (Elmore-Yalch 1998; National Center for Transit Research 2008). Given the high percentage of immigrants who rely on public transit when they first arrive and, therefore, have experience using public transit, immigrants are an important group around which many transit agencies ought to target their retention efforts.

Some transit agencies already have adopted strategies to better serve the needs of immigrants; however, the effects of these programs are unknown. For example, many agencies now provide transit information in multiple languages to improve the transit experience of linguistically-isolated riders. Language services must be only one component of much larger efforts to improve transit services targeted to immigrants. Overall, the specific transit concerns of immigrants tend to mirror those of non-immigrant transit riders (Lovejoy and Handy 2007). Immigrants want better spatial and temporal coverage, increased transit service frequency, improved in-vehicle and out-of-vehicle safety and comfort, and easier transfers. To better capture the immigrant market-and potentially slow immigrants' assimilation to cars-these types of transit service enhancements could be targeted to immigrant ports of entry, many still located in dense urban neighborhoods. Another promising approach is to develop alternatives to traditional fixed-route, fixed-schedule transit service. Such alternatives include a range of servicesboth formal and informal-such as taxis, vanpools, minibuses, jitneys, demandresponsive van services, station cars and bicycles, and limited route-deviation bus service, many of which immigrants already use (Garnett 2001; Kemper et al. 2007; Valenzuela et al. 2005).

In many cities, immigrants are an important and, in some places, the most important segment of the transit market. Immigrant reliance on transit, however, is waning, a disquieting trend for transit managers, particularly in places such as Los Angeles, New York, and Chicago, where immigration is slowing. To retain their most reliable customers, transit managers must understand the dynamics of immigrant travel behavior and the transit needs of their immigrant ridership. 
In some states such as California, failure to do so-holding all other trends constant-will have grave consequences for the future of public transit.

\section{Endnotes}

${ }^{1}$ In comparison, historical data on U.S. transit ridership show a 9 percent increase in transit ridership from 1980 to 2000 (American Public Transit Association 2008).

${ }^{2}$ These figures are in 2000 dollars, adjusted by the Consumer Price Index for urban consumers in the West.

\section{References}

American Public Transit Association. 2008. 2007 Public Transportation Fact Book. Historical Tables. Washington, D.C.: American Public Transit Association, January. http://www.apta.com/research/stats/factbook/documents/fact_ book_history_no_blanks_for_internet.pdf

American Public Transit Association. 2009. 2009 Public Transportation Fact Book. Part 3: Transit Agency and Urbanized Area Operating Statistics. Washington, D.C.: American Public Transit Association, April. http://www.apta.com/ research/stats/factbook/documents08/2009_fact_book_final_part_3.pdf.

Blumenberg, E. 2009. Moving in and moving around: Immigrants, travel behavior, and implications for transport policy. Transportation Letters 1(2): 169-180.

Blumenberg, E., and K. Shiki. 2007. Transportation assimilation: Immigrants, race and ethnicity, and Mode Choice. Conference Proceedings of the Transportation Research Board Annual Meeting, Paper \#07-2475, Washington, D.C.

Blumenberg, E., and M. Smart. Forthcoming. Getting by with a little help from my friends ... and family. Immigrants and carpooling. Transportation.

California Department of Finance. 2006. California population tops 37 million in 2005, adds nearly half a million according to new state demographic report. March 2. Retrieved June 2006 from http://www.dof.ca.gov/HTML/ DEMOGRAP/Estimates/E-2/E-2_2000-05_PressRelease.pdf.

Casas, J., C. Arce, and C. Frye. 2004. Latino immigration and its impact on future travel behavior. Conference Proceedings of the 2004 National Household Travel 
Survey Conference. Washington, D.C. Retrieved June 2006 from http://trb.org/ conferences/nhts/Casas.pdf.

Cervero, R. 1990. Transit pricing research: A review and synthesis. Transportation 17: 117-139.

Cervero, R. 2002. Built environments and mode choice: Toward a normative framework. Transportation Research Part D-Transport and Environment 7(4): 265-284.

Chapman, J., and J. Bernstein. 2003. Immigration and poverty: How are they linked? Monthly Labor Review 126: 10-15.

Council of Economic Advisors. 2007. Immigration's economic impact. Executive Office of the President, June 20. http://www.whitehouse.gov/cea/ cea_immigration_062007.pdf.

Elmore-Yalch, R. 1998. A handbook: Integrating market research into transit management. U.S. Federal Transit Administration, National Research Council, Transportation Research Board, Transit Development Corporation, Transit Cooperative Research Program.

Federal Transit Administration. Historical Data Files. TS1. Operating and Capital Funding. National Transit Database, http://204.68.195.57/ntdprogram/data. htm. Accessed July 7, 2009.

Garnett, N. 2001. The road from welfare to work: Informal transportation and the urban poor. Harvard Journal on Legislation 38(1): 173-229.

Gibson, C. J. and E. Lennon. 1999. Historical census statistics on the foreign-born population of the United States 1850-1990. Population Division Working Paper No. 29. U.S. Bureau of the Census, Washington, D.C., February.

Glaeser, E. L., M. E. Kahn and J. Rappaport. 2008. Why do the poor live in cities? Journal of Urban Economics 63: 1-24.

Gomez-Ibanez, J. A. 1996. Big city transit ridership, deficits, and politics: Avoiding reality in Boston. Journal of the American Planning Association 62(1): 30-50.

Heisz, A., and G. Schellenberg. 2004. Public transit use among immigrants. Canadian Journal of Urban Research 13(1): 170-191. 
Hendrickson, C. 1986. A note on the trends in transit commuting in the U.S. relating to employment in the CBD. Transportation Research Part A: General 20(1): 33-37.

Hill, L. E., and H. P. Johnson. 2002. Understanding the Future of Californians' Fertility: The Role of Immigrants. San Francisco: Public Policy Institute of California.

Kain, J. F., and Z. Liu. 1995. Secrets of success: How Houston and San Diego transit providers achieved large increases in transit ridership. Report prepared for Federal Transit Administration.

Kain, J. F., and Z. Liu. 1996. An econometric analysis of the determinants of transit ridership, 1960-1990. Report prepared for the U.S. Department of Transportation, Transport System Center, Cambridge, Massachusetts.

Kain, J. F., and Z. Liu. 1999. Secrets of success: Assessing the large increases in transit ridership achieved by Houston and San Diego transit providers. Transportation Research A 33: 601-624.

Kenworthy, J., and F. Laube. 2002. Urban transport patterns in a global sample of cities \& their linkages to transport infrastructure, land use, economics \& environment. World Transport Policy \& Practice 8(3): 5-19.

Kemper, R.V., J. Adkins, M. Flores, and J. L. Santos. 2007. From undocumented camionetas (mini-vans) to federally regulated motor carriers: Hispanic transportation in Dallas, Texas, and Beyond. Urban Anthropology 36(4): 381-423.

Lave, C. 1992. Cars and demographics. Access Magazine 1 (Fall): 4-7.

Logan, J. R., R. D. Alba, and W. Q. Zhang. 2002. Immigrant enclaves and ethnic communities in New York and Los Angeles. American Sociological Review 67(2): 299-322.

Lovejoy, K., and S. Handy. 2007. Transportation experiences of Mexican immigrants in California: Results from focus group interviews. Research Report, Institute of Transportation Studies, University of California Davis.

McCarthy, K. F., and G. Vernez. 1997. Immigration in a Changing Economy: California's Experience. Center for Research on Immigration Policy, Santa Monica, CA: RAND Corporation.

McFadden, D. 1974. The measurement of urban travel demand. Journal of Public Economics 3: 303-328. 
McGuckin, N., and N. Srinivasan. 2003. National Summary, Journey to Work Trends in the United States and its Major Metropolitan Areas 1960-2000. FHWA -EP03-058.

Ming, Z. 2006. Travel choice with no alternative-Can land use reduce automobile dependence? Journal of Planning Education and Research 25(3): 311-326.

National Center for Transit Research, Center for Urban Transportation Research. 2008. Transit Ridership, Reliability, and Retention. Final Report. University of South Florida. October. FDOT BD-549-32.

Myers, D., J. Pitkin, and J. Park. 2005. California Demographic Futures: Projections to 2030, by Nativity, Immigrant Generations, and Time of Arrival in the U.S., Full Report. Population Dynamics Research Group, School of Policy, Planning, and Development. Los Angeles, CA: University of Southern California.

Myers, D. 2008. Thinking ahead about our immigrant future: New trends and mutual benefits in our aging society. Immigration Policy in Focus 6(1): 1-11.

Myers, D., J. Pitkin, and J. Park. 2005. Demographic futures project: Projections to 2030, by immigrant generations, nativity, and time of arrival. Population Dynamics Research Group. Los Angeles, CA: School of Policy, Planning, and Development, University of Southern California.

Passel, J., and D. Cohn. 2008. U.S. Population Projections: 2005-2050. Washington, D.C.: Pew Research Center.

Pisarski, A. 1999. Cars, women, and minorities. The Democratization of Mobility in America. Automobility and Freedom Project, November. Accessed June 2006. http://www.cei.org/PDFs/pisarski.pdf.

Polzin, S. E., and X. Chu. 2005. A closer look at public transportation mode share trends. Journal of Transportation and Statistics 8(3): 41-53.

Polzin, S. E., X. Chu, and J. R. Rey. 2000. Density and captivity in public transit success: Observations from the 1995 Nationwide Personal Transportation Study. Journal of the Transportation Research Board 1735: 10-18.

Rosenbloom, S. 1998. Transit Markets of the Future. The Challenge of Change. Transit Cooperative Research Program, Report 28. Washington, D.C.: National Academy Press.

Ruggles, S., M. Sobek, T. Alexander, C. A. Fitch, R. Goeken, P. K. Hall, M. King, and C. Ronnander. 2004. Integrated Public Use Microdata Series: Version 4.0 
(machine-readable database). Minneapolis, MN: Minnesota Population Center. http://ipums.org.

Schimek, P. 1996. Household motor vehicle ownership and use: How much does residential density matter? Transportation Research Record 1552: 120-125.

Singer, A. 2004. The Rise of New Immigrant Gateways. Washington, D.C.: Brookings Institution. http://www.brookings.edu/urban/pubs/20040301_gateways.pdf

Tal, G., and S. Handy. 2010. Travel behavior of immigrants: An analysis of the 2001 National Household Transportation Survey. Transportation Quarterly 17(2): 85-93.

Taylor, B. D., and W. S. McCullough. 1998. Lost riders. Access 13: 26-31.

Taylor, B, D., D. Miller, and H. Iseki. 2009. Nature and/or nurture? Analyzing the determinants of transit ridership across US urbanized areas. Transportation Research Part A-Policy and Practice 43(1): 60-77.

Transportation Research Board. 1997. Building Transit Ridership. An Exploration of Transit's Market Share and the Public Policies that Influence It. Washington, D.C.: National Academy Press.

Urban Institute. Neighborhood Change Database [NCDB] Tract Data from 1970-2000. Accessed March 2006 from http://www.geolytics.com/ USCensus,Neighborhood-Change-Database-1970-2000,Products.asp.

U.S. Census Bureau (1990). Summary File 3. http://factfinder.census.gov/ servlet/ DatasetMainPageServlet?_program=DEC\&_tabld=DEC2\&_ submenuld=datasets_18_lang $=$ en\&_ts $=265059729452$.

U.S. Census Bureau (2000). Summary File 3. http://www.census.gov/Press-Release/ www/2002/sumfile3.html

U.S. Department of Homeland Security. 2008. Yearbook of Immigration Statistics: 2008. Washington, DC: Office of Immigration Statistics. http://www.dhs.gov/ ximgtn/statistics/publications/yearbook.shtm.

U.S. Government Accountability Office. 2005. Transportation Services: Better Dissemination and Oversight of DOT's Guidance could Lead to Improved Access for Limited-English Proficient Population, GAO-06-52. Washington, D.C.: U.S. Government Accountability Office. 
Valenzuela, A., Jr., L. Schweitzer, and A. Robles. 2005. Camionetas: Informal travel among immigrants. Transportation Research Part A-Policy and Practice 39(10): 895-911.

\section{About the Authors}

EVelyn Blumenberg (eblumenb@ucla.edu) is Associate Professor of Urban Planning in the Department of Urban Planning at the University of California, Los Angeles (UCLA) School of Public Affairs. Her research focuses on travel demographics, particularly the role of transportation in facilitating the mobility needs of welfare recipients, the urban poor, and low-income women. She received a Bachelor of Arts degree in Political Science from the University of California, Berkeley and a Master of Arts degree and Doctorate in Urban Planning from UCLA.

AleXANDRA Evans (alexandra.evans@la.gov) received a Bachelor of Arts degree in Political Science and a Master of Arts degree in Urban Planning from UCLA. She currently is the American Recovery and Reinvestment Act Administrator and Director of Hurricane Recovery Special Projects in Transportation, Coastal Protection and Environmental Policy Advisor for the Louisiana Recovery Authority. 